УДК 782.8

doi 10.17072/2219-3111-2021-4-13-24

Ссылка для цитирования: Klopfenstein M. The Operatics of Death: Gender, the Market, and the Reform-Era Public Sphere in the Death of Angiolina Bosio // Вестник Пермского университета. История. 2021. № 4(55). С. 13-24.

\title{
THE OPERATICS OF DEATH: GENDER, THE MARKET, AND THE REFORM-ERA PUBLIC SPHERE IN THE DEATH OF ANGIOLINA BOSIO
}

\section{Klopfenstein}

National Fellowships and Scholar Programs, University of South Carolina, Columbia, South Carolina, 29208, USA matthew.klopfenstein87@gmail.com

ORCID: 0000-0003-0270-7520

ResearcherID: ABF-9242-2021

Scopus Author: 57222196910

This article analyzes the development of a gendered culture of celebrity in nineteenth century Russia using the death of the opera singer Angiolina Bosio in 1859. Bosio was one of the leading celebrities of her era, and her death became a major social phenomenon. The article examines reactions to the singer's death in the capital press to demonstrate that the figure of the celebrity female performer reflected major changes in the public sphere during the era of the Great Reforms. Reactions to Bosio show that female opera stars reflected the growing role of commercial forces in the public sphere and the anxiety about them from the point of view of many commentators. This article demonstrates that female celebrities reveal the dynamics of an expanding public sphere in Russia that was visible in the pages of the press. Bosio embodied both the ambiguous status of opera as both a popular and elite artistic genre, and a distinct emotional culture associated with opera. Her death shows the role of gender in the creation and dynamics of the role of celebrity in the textual public sphere. Analyzing reactions to Bosio's death clearly demonstrates that gendered tropes and conventions from opera spread widely beyond the theater and influenced public life. Through the prism of her death, we can see the development of a public sphere in the which cultural boundaries blurred and European-wide operatic conventions became a model for public behavior.

Key words: Media, death, public sphere, gender, opera, celebrity, Great Reforms.

The death of the prima donna Angiolina Bosio in March 1859 in St. Petersburg was not merely a cultural event: it was a public spectacle that brought the dramatic conventions of opera to the pages of the press and made visible accelerating changes in the imperial Russian public sphere. Only twentynine years old, Bosio (1829-1859) had established herself as the main star of the Imperial Italian Opera in St. Petersburg. After she fell ill during a tour of Moscow, news of her sickness spread quickly upon her return to the capital. For days before her death from inflammation of the lungs on March 31 , Bosio was inundated with visits from her adoring public, who flooded the drawing room of her home in search of the latest updates on her condition. As one posthumous account noted: "The public clearly displayed their sympathy and love to her during her illness. Her drawing room was constantly overflowing with people who came to find out about her health". Bosio herself was portrayed as someone who "treasured the attention and affection of the public to the last minute" (Замечательныя женщины..., 1860, с. 57).

Reactions to the death of Angiolina Bosio reveal the ways in which members of Russia's urban middle classes participated in a larger European culture of opera fandom in which the figure of the prima donna served as a potent symbol for the role of celebrity, media, and the marketplace in public life. This was a death of dramatic proportions in which behaviors and features associated with opera emerged as visible markers of an emerging public sphere. A highly visible illness and death turned into a massive public funeral as Bosio's fans asserted the right to participate in events surrounding their idol, taking to the streets by the thousands for the funeral and burial procession. A socially diverse public, united by shared taste, a common sense of loss, and undoubtedly some element of mor- 
bid fascination, eagerly followed all details of the singer's demise. Celebrity fascination, voyeuristic attention to the dying body, and commercialism mingled together with demonstrative public grieving, performative emotional acts, and the close attention of the press. Commentators reflected on the death in ways that implicitly asked if such developments were signs of a growing civil society or merely an intense but ultimately fleeting expression of infatuation.

The fascination and implicit anxiety that accompanied responses to Bosio's death demonstrate that female performers were not only key subjects of public discourse in the Reform Era: they were also emblematic of new forms of public life that reflected the growing influence of market forces and the blurring of cultural and social boundaries. The operatic scale and qualities of Bosio's death reflected the dynamics of an expanding public sphere in the era of the Great Reforms. The Russian Empire stood on the threshold of major transformations when Bosio died. Long-term social and cultural developments stood alongside the tsarist state's own decades-long efforts at bureaucratic reform aimed at dealing with the challenges of a modernizing world [Lincoln, 1990]. The period from 1857 to 1864 saw the drafting, debating, and implementation of far-reaching reforms, the most consequential of which was the abolition of serfdom in 1861 . Conditions for a new kind of society now emerged: the creation of zemstva, the restructuring of the justice system, and the partial relaxation of censorship collectively created new economic possibilities, a demand for educated professionals, and an expanded commercial press [Lincoln, 1990; Clowes, Kassow, West, 1991; Eklof, Bushnell, Zakharova, 1994]. This last development was a crucial factor driving the expansion of an urban public sphere. The late 1850 s and early 1860s saw major growth in the number of newspapers and journals. In the period from 1856-1860 approximately 150 new publications launched, a fivefold increase over the period from 1851-1855 [McReynolds, 1991, p. 18]. These developments reflected the extent to which the "general interest newspaper" had emerged as the "primary medium of public opinion" in the Reform Era for the urban middle estates that made up the bulk of Russia's reading public [Dianina, 2003, p. 189].

The world of theater and performance was a crucial element of the larger changes unfolding in Russia. While Russia's major theaters remained concentrated in St. Petersburg and Moscow, they reached an expanding audience from a wider range of backgrounds. The population of the Empire increased twofold from 1800 to 1860 , with the urban population increasing its share of the population to $10 \%$. This was reflected in the increasingly diverse audiences attending the theater in major cities [Frame, 2006, p. 55]. The empire's growing number of theaters became, in Murray Frame's words, "mirrors of society" that "reflected a growing diversity of social groups" and even amid the reign of Nicholas I had already "emerged as a significant factor in public life" [Ibid., p. 73]. The expanding world of the arts, something that predated the reforms, created new public spaces and signified a trend that continued to play out in subsequent decades in which elite tastes were "being crowded - though not replaced - by new publics with new tastes and more sites for seeing and buying art and performance" [Stites, 2005, p. 423]. In both Russia and the larger European world, female opera performers came to represent these larger changes in the public sphere. The death of Angiolina Bosio provides a striking case study of the ways in which the gendered figure of the female celebrity performer embodied the ambiguities and anxieties of Russia's changing public life, revealing the formation of an increasingly heterogeneous urban public sphere shaped by the conventions of opera and increasingly constituted by an expanding commercial press.

\section{The World of Opera and the Public Performance of Death}

Opera emerged as a major force for the creation of urban popular culture in Russia in the decades surrounding the Great Reforms. The major opera houses in the Russian Empire, such as the Bol'shoi Kamennyy Theater in St. Petersburg and the Moscow Bol'shoi Theater served as spaces in which aristocratic audiences and those with more aspirational tastes gathered together [Buckler, 2000, p. 16-25]. As Julie Buckler has argued, opera in nineteenth-century Russia should be seen as a "middlebrow art" that represented "an eclectic sphere of popularized elite art and entertainment forms for a rapidly growing number of city dwellers". Consequently, "the cultural middle ground in Russia" was "the place where opera could truly circulate socially" [Ibid., p. 2]. Opera's broad social appeal transcended borders and created an international world of performance and celebrity, with leading stars touring throughout Europe and beyond and becoming major public personalities through the growth of the press [Ther, 2014, p. 2, 8, 19-23]. As such it entered into a broader popular culture that went "far beyond the elite houses of the European and American capitals" [Rutherford, 2006, p. 21]. Encapsulat- 
ing these trends, Philip Ther notes: "Opera was the cultural institution of the nineteenth century" [Ther, 2014, p. 1].

The figure of the prima donna loomed large in this world and represented the ambiguities of opera's social and cultural status. The leading women of the opera came to represent new models of womanhood through their public visibility and became commodified objects of desire in a commercial society in which a carefully managed public image developed through the press was central [Rutherford, 2006, p. 16, 22-23; Cowgill, Poriss, 2012, p. XXX-XXXV]. Popular biographies of singers became common throughout Europe in the early 1800s, and by the 1860s prima donnas in particular were frequently the subject of such treatment. At the same time, female opera stars were increasingly tied to the traits of the prima donna persona, a gendered construct of the male gaze which encompassed "vanity, self-dramatization, capriciousness, irritability, and glamor" to such a great extent that "a singer's relationship to the 'prima donna' archetype ... became as significant in shaping her reception as did her onstage performances, vocal profile, physical attributes, and personal qualities" [Cowgill, Poriss, 2012, p. XXVII, XXVIII]. These tropes were just as much at work in Russia as in other parts of Europe, where the idealized type of the prima donna came into conflict with the economic and social realities undergirding opera. Deified as the embodiment of genius and art, the prima donna's status as a working woman simultaneously "compromised her status as deity of the arts and even suggested an affinity with servants, shopgirls, and prostitutes" [Buckler, 2000, p. 79]. This ambiguous status was reinforced by the commodification of opera stars through a vibrant trade in their images that flourished on both sides of the Atlantic and in Russia [Ibid., p. 84]. While commodified as an object of erotic fascination, the prima donna was a multifaceted figure at the center of larger discourses of gender and represented new possibilities for women in public. As Susan Rutherford argues, "no other woman ... in this era encompassed such a range of interpretive possibilities, was both so idolized and so despised; she was, in short, a living metaphor for her sex" [Rutherford, 2006, p. 34].

Both the profound social changes shaping Russia and the features of a larger, European-wide operatic culture were on display in the life and death of Angiolina Bosio. Bosio's path to stardom on the Russian stage was circuitous. Born in Italy, her father was a "poor singer" who placed his daughter in a Milan boarding home where she studied music and at age fifteen caught the eye of a benefactor who paid for her formal musical education and secured her first professional engagements. Bosio lived an itinerant life as an opera performer, appearing on stage in numerous cities in Europe and the Americas in her professional career, including Milan, Madrid, Copenhagen, London, New York, Havana, and Paris, before spending her final four years (1855-1859) with the Imperial Italian Opera in St. Petersburg (Анджиолина Бозио // Русский художественный листок, 1859, с. 35; Общественная жизнь в Петербурге, 1859, с. 70; Panonopm, 1859, с. 2). These frequent travels located Bosio firmly in the international world of opera that stretched across the Atlantic from the United States and into Europe, the Russian Empire, and the Eastern Mediterranean. Opera, perceived to be a distinctly European cultural form and therefore a marker of status, enjoyed particular popularity at the edges of the European world [Ther, 2014, p. 8]. Bosio's career in Russia coincided with what Julie Buckler has termed the "Italian opera craze" - the period from 1843-1886 in which Italian operas dominated the Russian stage and exerted a powerful influence on entertainment tastes and social life in the leading cities [Buckler, 2000, p. 36-48].

Despite her foreign origins and relatively short time in Russia, Bosio was enthusiastically embraced by the opera-going public of St. Petersburg and was made an honorary citizen by Alexander II, who bestowed upon her the official title of His Majesty's Singer (Фельтон, Санкт-Петербургские ведомости, 1859, с. 321). Н. Sutherland Edwards, a British journalist in attendance at the coronation of Alexander II in 1856, reported that the audience was so enraptured by a performance of Bosio's "on the occasion of the Czar's coronation at Moscow" that they burst into spontaneous applause, "notwithstanding the well-known rule which forbids applause in the presence of the Emperor" (Death of Madam Bosio, 1859, p. 3). She garnered praise for her performances in the operas of Gioachino Rossini such as The Barber of Seville and Le comte Ory, but it was in the works of Verdi, above all her role of Violetta in La Traviata, that she won acclaim [Кублицкий, 1874, с. 203-204]. In the wake of her death, reporters were quick to stress the degree to which she had experienced the public's devotion, with one commentator stressing that Bosio "enjoyed the unusual love of the Petersburg public" (Hoвости и слухи, 1859, с. 314). Indeed, the trope of St. Petersburg as a cold and forbidding city that had 
been touched by a "delicate flower" and a "daughter of the South" was frequently repeated in the aftermath of her death (Фельтон // Русский инвалид, 1859, с. 1; Анджиолина Бозио // Русский художественный листок, с. 35). In embracing and seeking to domesticate Bosio, Russian audiences laid claim to opera's international cultural prestige and positioned themselves as worthy partakers in it.

In responding to Bosio's demise, Russian audiences eagerly engaged in the kind of intense fandom associated with prima donnas around the world. Bosio's home was constantly besieged with curious fans and admirers eager for any updates about her health. One account declared that her drawing room was "not left empty for a single minute" (Кончина и похороны г-жи Бозио, 1859, с. 36). Another observer described the crowds as "attacking" her residence in the Demidov House on Nevskiy Prospect with their inquiries after her health and reported that some admirers remained at Bosio's bedside at all times. When news of her death was finally announced there was a "constant rotation of carriages" outside her door as more people flocked to see the singer's body. In her apartment the coffin where her body lay was perpetually covered with flowers brought by mourners, who came from "all ranks and estates" (Дневник знакомаго человека // Иллюстрация, 1859, № 63, с. 238). Such interest in the health and body of a famous figure was not unprecedented in Russia, as demonstrated by the huge, excitable crowds that clamored to be near Pushkin's body two decades earlier [Binyon, 2003, p. 607-8, 610]. Bosio's death, however, was a distinct extension of the world of opera.

Reactions to Bosio's illness and death suggested that these events were viewed as part of a larger performance meant for public consumption and inviting operatic behavior. A distinct culture surrounding opera had developed in Russia by the mid-nineteenth century that featured increasingly ritualized performative gestures such as showering the stage with flowers, public crying, and emotional outbursts by members of the audience. This represented, in Julie Buckler's words, "the institutionalizing [of] the spontaneous excesses that opera inspired" [Buckler, 2000, p. 42]. This context gives new meaning to Bosio's packed drawing room and coffin, which was overflowing with flowers brought by admirers. In the performance space of Bosio's apartment, her flower-covered coffin resembled an opera stage after a production. Attention to the behaviors and practices of the crowds surrounding Bosio reported in the press lends further support to this attention to operatic conventions. The eagerness with which fans inserted themselves into Bosio's domestic space and the way in which Bosio allegedly saw her own illness as a sort of performance for this audience show that her illness and access to her body were seen as public matters. It also provides evidence of behaviors that reflected operatic conventions, suggesting that the emotionally effusive culture of opera was making its way into other aspects of public life.

The diary of Mikhail Voevodskiy, a bureaucrat in the Ministry of Foreign Affairs, provides a striking firsthand account of these events that reveals qualities of operatic fandom. In an entry dated April 1, 1859, he recorded the news of the singer's death the previous day and stated, "I went around to her apartment in the Demidov House on Nevskiy Prospect to pay respects to her body". After doing so, "I took [my sisters] Manya and Lizenka there, and then I sent Mashenka, Katya, and Olya." These multiple visits to view Bosio's body were evidently insufficient, for in his entry for April 2, Voevodskiy wrote, "today at 3 I left the Department with [my colleagues] Saburov and Lents to look at Bosio again". This time he expressed shock at the appearance of the body, recording "we found her already lain in the coffin and terrible changed". He reported that the three of them returned that night to a nearby tavern to wait more than two hours to join those carrying Bosio's body from her apartment to St. Catherine's Catholic Church, where the funeral service was to be conducted. An hour and half before the body was to be removed, the crowds in front of the house were already so large that it was no longer possible to pass through Nevskiy. Despite their early arrival, Voevodskiy and his friends were unable to get inside the church due to the large crowd (Воеводский, 1918, с. 31, 32). Voevodskiy's laconic account nonetheless reveals a government official so taken with Bosio that he went to view her body on three separate occasions in two days, bringing family members and work colleagues along. Such repeated viewings of the body once again suggest something akin to a performance. Rather than simply coming to pay final respects to Bosio, Voevodskiy returned time and again, like an enraptured theater enthusiast returning to see a production multiple times.

Voevodskiy's close attention to the condition of the body, while only mentioned briefly, is indicative of the ways in which performance, death, and the female body were powerfully linked in nineteenth century European culture. His lament over the seemingly significant change in the state of 
the body, made only a day after first viewing it, shows the level of scrutiny with which he observed Bosio's corpse. He was not alone in doing so: other mourners lamented "the death of a young woman in the full flower of her life," spoke repeatedly of her "lifeless corpse," and treated her death as a parallel to the death of Violetta in La Traviata (Анджиолина Бозио // Русский художественный листок, с. 36; Анджиолина Бозио // Северный цветок, 1859, с. 230) [Buckler, 2000, p. 133]. These responses suggested that death, opera, and the female body were seen as naturally related. Once more, the conventions of opera provided a script for mourners to articulate and process their grief over their idol's death. Feminist musicologists and scholars of opera have repeatedly shown the extent to which the trope of female death was reinforced through literary and musical techniques in nineteenth century opera [Clément, 1988; McClary, 1991]. Art scholars have furthermore noted the pervasive depiction of dead and dying women throughout the nineteenth century and fin de siècle, arguing that such representations expressed masculine anxiety over changing gender roles and the unstable nature of femininity [Dijkstra, 1986; Bronfen, 1992]. Such anxiety was clearly on display in the Russian press, which fixated on Bosio's death in ways that made her a cipher for larger changes in the mid-nineteenth century public sphere.

\section{Consuming Bosio: Gender and the Commodification of Celebrity}

By both reproducing Bosio's image and debating the commercialism surrounding it, the press emerged as a major force for mediating and contesting Bosio's celebrity status. The ambiguous reactions of the press demonstrated the significant place of operatic culture in public life and the misgivings that many observers felt about aspects of it. The role of the leading newspapers and journals in reflecting, promoting, and debating the public's fascination with Bosio was significant, as her death occurred at a transitional moment in the development of the Russian press. While theater and the performing arts had attracted attention in newspapers and thick journals, the number of specialized publications focused on music and the stage was about to increase dramatically. At least forty-two publications dedicated to theater and performance, broadly defined, appeared in the period from 1774 to 1855 , while eighty-four new publications would appear in the following half century [Вишневский, 1941, с. 19-55]. These publications were largely limited to St. Petersburg and Moscow. Still, the many publications that drew attention to her death demonstrated the increasing significance of art and performance to an expanding public sphere in the capitals.

Indeed, many who mourned Bosio saw the press as a means of expressing their grief. Teatral'nyy i muzykal'nyy vestnik published a tribute poem by a certain A. I. Antonov, "one of her numerous fans" (Кончина Анджиолины Бозио, 1859, с. 1). Sankt Peterburgskie vedomosti declared that the paper had been inundated with poems and other verses in honor of Bosio to such a degree that "they could fill every column of our paper for several days, to the great detriment of domestic and international news, political questions, and vitally-important telegraph dispatches." The paper described these works as "more or less poetic" and deigned to reprint one worthy example sent by a certain "Mr. Vl. G - n" (Петербургская летопись, Санкт-Петербургские ведомости, 1859, 19 апреля, с. 363). While clearly casting aspersions on the artistic merits of these poems and suggesting that they did not warrant attention compared to "real" news stories, the decision to discuss the poems and print one suggested that the paper felt some pressure to respond to a public outpouring of grief that sought to use the press as a means of expression.

Responses to Bosio's death revealed that gendered treatments of celebrity women in the press served to negotiate the uneasy relationship between art and commerce in Russian society. As a prima donna, Bosio embodied the ambiguous status of a figure who represented the ideals of art and was a commodified object of desire. These tensions could be seen in press accounts of the preparations for the singer's April 4 funeral. On April 1 a group of university students insisted on carrying Bosio's coffin by hand from her apartment to the church where the funeral service was to be conducted. Echoing Voevodskiy's description, the writer noted an immense crowd that filled Nevskiy near the house to witness the event and declared that the crowd was almost entirely made up of "all the youth of Petersburg" (Фельтон // Русский инвалид, 1859, с. 1). On the day of the funeral a massive crowd once again gathered outside. Due to the intense crowding, entrance into the church was strictly regulated by tickets (Кончина и похороны г-жи Бозио, 1859, с. 36). Voevodskiy again provided a window onto the proceedings. After arranging with another acquaintance to bring him and a friend into the church for the funeral, Voevodskiy learned that "tickets were being distributed in the deceased's apartment" 
for the funeral and after "lengthy exertions we succeeded in getting three tickets - one for money" (Воеводский, 1918, с. 31). While the use of tickets to control crowds at notable funerals was a common practice throughout Europe in the nineteenth century (see for example, [Curl, 1972, p. 17]), Voevodskiy's account indicates that Bosio's funeral had in part turned into a commercial venture, with some willing to take advantage of the significant demand for tickets by selling them. This scene of a crowd of admirers clamoring for tickets brings to mind images of box office lines at a theater. The eager crowds that had flocked to the Bol'shoi Kamennyy Theater to see Bosio now struggled for a ticket to her final performance: her funeral.

The uneasy juxtaposition of funeral rites and the hawking of tickets reflected the larger discomfort many Russian commentators felt about the growing role of the market in the arts and society. Critical judgments of what to a large extent were the economic realities of the opera appeared in several reactions to Bosio's death. Bosio was typical of female opera singers of her generation in Europe and the North Atlantic, all of whom, except a tiny group of the most famous stars, experienced enormous financial uncertainty due to the mercurial tastes of audiences and the prospect of career-ending health problems [Rutherford, 2006, p. 185]. Even while enjoying the height of her popularity in St. Petersburg and the greater financial stability that came with it, she still spent the summer season in London each year (Общественная жизнь..., 1859, с. 70). Indeed, it was in response to a "very lucrative engagement" that Bosio had traveled to Moscow in March despite, the newspapers claimed, the fact that she was already not feeling well (Кончина и похороны..., 1859; Фельтон // Нувеллист, 1859, c. 36). Her performances there were received tepidly by the local press, a fact that the feuilletonist for Sankt Peterburgskie vedomosti attributed to her having to perform less demanding parts of her repertoire due to her worsening illness (Фельтон // Санкт-Петербургские ведомости, 1859, с. 321). Additionally, a writer from the literary journal Russkoe slovo reported that Moscow audiences were "dissatisfied" by the "high prices set by the organizers of the concerts" (Общественная жизнь..., 1859, с. 71).

These discussions were highly gendered, reflecting an implicit discomfort with women publicly engaging in financial matters. Press accounts carried more than a hint of judgment, suggesting that she had compromised her own health in pursuit of money. This reflected a larger European discourse on opera singers, who were frequently portrayed as greedy in the press. As Susan Rutherford observes, "Both male and female singers were implicated in this prejudice; but women suffered more from the distance between conventional gender images and reality" [Rutherford, 2006, p. 188]. Such details were not lost on contemporaries. Avdot'ya Panaeva declared in her memoirs that the singer "paid with her life for her stinginess," and asserted that she went to Moscow despite constantly receiving valuable gifts from admirers and being warned by her doctor that she could take ill from the cold weather ( $\Pi a-$ наева, 2002, с. 121). Perhaps in an effort to protect Bosio from such allegations, others sought to read noble intent into her journey. Teatral'nyy $i$ muzykal'nyy vestnik portraying her concerts as proof of a dedicated artist who had promised to perform and refused to break an engagement, and Sankt Peterburgskie vedomosti, in response to allegations in Moscow that Bosio had a hand in setting the ticket prices, clarifying in a footnote that ticket prices had been set by the organizers of the event and not Bosio herself (Panonopm, 1859, с. 2; Фельтон // Санкт-Петербургские ведомости, 1859, с. 321). A goddess on stage, Bosio's actual status as a working woman was socially suspect and for her most ardent defenders something to be discretely obscured behind the image of an artist motivated by higher, aesthetic concerns.

This concern with the effects of a nascent capitalism went hand in hand with an emerging culture of commodified celebrity surrounding famous performers, particularly female opera stars. New media developments, particularly printing improvements that allowed for more sophisticated reproduction of images, played a key role in this process. Images of prima donnas in the form of lithographs, photographs, and small busts made opera stars objects to be collected in addition to persons to be admired [Buckler, 2000, p. 84-94]. This proliferation of images made the human, and especially female, body a consumable cultural object. Surveying female celebrities in European culture from the 1850s to 1950s, Sabine Chaouche and Clara Sadoun-Édouard stress that "the body became fashionable, not to say one of the most important components and vehicles of popular culture" through the rise of new visual technologies and practices of advertising [Chaouche, Sadoun-Édouard, 2015, p. 12]. The 1850s marked a particular turning point in the production of mass media imagery with the creation of the carte de visite, a pocket-sized photographic format that could be produced in greater quanti- 
ties at lower prices than existing printing methods allowed. By the late 1850s and early 1860s it had become a ubiquitous commercial format used to portray everyone from Queen Victoria to common vaudeville performers in Paris [Senelick, 1991, p. 1-2; Rowley, 2013, p. 19-20, 78-79]. Bosio was very much a part of this world, with small photographs and sketches of her in costume produced during her lifetime (see for example, РГАЛИ. Ф. 2430. Оп. 1. Д. 1388).

Interest in images of Bosio only accelerated in the wake of her death. "Baron X", a feuilletonist for the journal Russkiy mir, reported that on the day that Bosio's body was brought to the church her portrait was sold in "all the music stores". One store even displayed a bust of Bosio veiled in funereal cloth. This commentator interpreted the gesture not as an act of tribute but as a crassly commercial means of advertising the collectible busts of the singer already on sale: "the trick worked; they say that all the busts were sold; the same thing happened in other stores - even in those that did not resort to such clever tricks" (Барон Икс, 1859, с. 353). Such collectible images remained popular in the weeks following Bosio's death. Sankt Peterburgskie vedomosti drew attention to a photograph of Bosio taken by the artist and photographer Martin Karlovich Wagenheim, which was sold in the aftermath of her death (Петербургская летопись // Санкт-Петербургские ведомости, 1859, 19 апреля, с. 363). Advertisements for the photo, which was sold for 1 ruble and 50 kopecks, appeared in the paper for more than a month after Bosio's death (See for example the editions from May 5, 6, and 7). On May 10 the paper declared that "the name of Madame Bosio continues to be repeated", in part due to "the photographic portraits of the famous singer" being sold by "nearly all Petersburg photographers" (Петербургская летопись // Санкт-Петербургские ведомости, 1859, 10 мая, с. 440). Such images became important means of commemorating the singer while also serving as a profitable business opportunity. Bosio's death became an economic opportunity to capitalize on public fascination and bring it into an emerging marketplace of celebrity.

Even as commentators voiced disapproval over attempts to profit from Bosio's death, many publications were quick to produce their own images. While the illustrated weekly publication Illiustratsiya was only able to publish a lengthy print description of Bosio's funeral in the first issue after her death, readers were reassured that "we will present a portrait of Madame Bosio in the next issue" (Дневник знакомаго человека // Иллюстрация, № 63, с. 239). The cover of the following issue did indeed feature a large lithograph of Bosio, shown from the waist up with a reproduction of her signature alongside the image. An even more elaborate image appeared in the May 1 issue of Russkiy khudozhestvennyy listok, which consisted solely of a lengthy article on Bosio's death. An image of Bosio appeared as the centerfold of the issue, printed on a heavier stock of paper indicating its status as a collectible item. On it Bosio, portrayed in a sumptuous gown, was surrounded by a garland bearing the names of her most famous opera roles. Below her image was a reproduction of her signature, under which appeared an image of a fresh grave topped with a simple wooden cross (Русский художественный листок, 1859, с. 35-36) [Buckler, 2000, p. 140-141]. The image, while clearly meant to celebrate the singer as a great artist, also linked Bosio with her death and her ambiguous social status. Appearing underneath the heading "Violetta" - the courtesan who dies of tuberculosis at a young age at the end of La Traviata - and above an image of a grave, Bosio's image is physically positioned between a reference to her role as a public woman both literally and figuratively through the character Violetta and her death. The appearance of Bosio's signature in these representations also clearly marked them as publicity images part of the growing marketplace of celebrity. This was on display two years later, when a monument to Bosio ordered by her husband and constructed in Italy was installed above her grave. Nuvellist offered a detailed description of the statue and ended by stating "we hear that in the near future photographic images of Bosio's monument" would be appearing that would be "good gifts" for fans of the singer (Памятник Бозио, 1861, с. 79). Even in death Bosio's media imagery bore the markings of commodification.

Interest in collecting Bosio, and the potential opprobrium it spawned, was not limited to lithographs, photographs, and miniature busts. A feuilleton in the May 14 issue of Illiustratsiya drew attention to the posthumous sale of Bosio's belongings organized by her husband at her Nevskiy apartment. After noting the presence of such valuables as jewelry, furniture, and Bosio's wardrobe, the writer sarcastically observed that "enraptured loudmouths have the chance to prove their devotion to the memory of the famous artist." The entire sale was described with thinly veiled disdain, as when the author noted that it was organized by "her main heir, her husband," who was described as "planning 
on the lucrative sale of all the trifles of the former Petersburg darling" (Дневник знакомаго человека // Иллюстрация, 1859, № 69, с. 307). Identifying Bosio’s husband first as an heir and then as a spouse left no doubt as to the writer's assessment of his motives and served to implicitly color his relationship to Bosio as more financial than intimate. The description of Bosio's fans as emotionally overwrought "loudmouths" and the claim that their devotion could best be shown through purchasing her belongings simultaneously showed disdain for the intrusion of finances into the world of art while tying it to the intense level of devotion that the singer had inspired. Such descriptions of the "public sale" drew implicit attention to Bosio's status as a "public woman" of sorts in the theater. Indeed, this article is striking in another respect in that it mentions Bosio's husband at all. Despite the well-known fact that she was married to a Greek national, a certain Mr. Xindavelonis, almost no coverage in the leading Russian newspapers and arts journals made any mention of his existence (A rare exception is Памятник Бозио, 1861, с. 78-79). His negative portrayal in this mention is telling. Lenard Berlanstein, in a study of actresses in nineteenth century France, notes that actresses were seen as acceptable objects of male sexual fantasy such that the idea of a married actress was looked down upon and their husbands were often ridiculed by the press [Berlanstein, 2001, p. 105-109]. It is likely that a similar dynamic was at work in Russia with Bosio. Panaeva's memoirs echo the negative tone of Illiustratsi$y a$, stating that "[Bosio's] husband carried out a lucrative scam, selling all her things at expensive prices." She went on to claim that a male acquaintance of hers who was "not a wealthy person" had purchased a broken comb for ten rubles which ostensibly belonged to Bosio but which she asserted actually belonged to Bosio's maid or her husband, whom she labeled a "swindler" (Панаева, 2002, c. 121-122). V. A. Bernatskiy, reflecting on Bosio in a 1916 article in Russkaya starina, creatively extrapolated from Panaeva's diary to rescue the singer from accusations of greed, declaring that it was Bosio's husband who drove her to Moscow for the fatal performances (Бернаикий, 1916, с. 20-21). For Bernatskiy, Bosio's husband served as a convenient scapegoat for avoiding the troubling ambiguities of her status as cultural goddess and public woman.

Such criticisms implicitly and explicitly positioned the devoted fans of Bosio as men besotted with a captivating woman, revealing the gendering of opera fandom in the mid-nineteenth century. While by the early twentieth century operatic fandom was characterized, and indeed pathologized, as something feminine, in the mid-nineteenth century the most devoted fans of opera were the male melomany, or music lovers [Fishzon, 2013, p. 79-80]. Furthermore, in the nineteenth century the role of the collector was gendered male, with many men collecting the portraits of famous performing women [Buckler, 2000, p. 40-41]. Collecting was portrayed as a sign of discerning taste and a meloman's passion for the opera was treated as a mark of cultural sophistication, yet depictions of Bosio's fans frequently focused on erotically charged male behavior. While Bosio had many female admirers, it is striking that both in press accounts and in the memoirs of Voevodskiy and Panaeva it is men who are shown desperately striving to gain access to Bosio's body or claim a piece of her property. The extent to which Bernatskiy sought decades later to protect Bosio from the unseemly implications of being a public object of desire is itself telling. He allowed that "she had a multitude of fans, but this adoration was purely platonic because she was a woman of high moral standards" (Бернаикий, 1916, с. 20). In the very next paragraph, however, he recounted the story of N. I. Samoilovich, an instructor at a Petersburg military school, who was so taken with Bosio that he abandoned his duties to follow her on tour in Europe and lost his job as a result (Ibid., p. 20). Additionally, he wrote of another instructor, a certain Ozemblovskiy, whose dying wish was to be buried with sheet music that he had received from Bosio (Ibid., p. 22). While a true meloman was moved purely by music and aesthetic motives, the actions of Voevodskiy, Panaeva's acquaintance, the instructors described by Bernatskiy, and the (all-male) university students clamoring to carry Bosio's casket reveal men as infatuated and enthusiastic participants in celebrity culture that at times exceeded the bounds of respectable masculine public behavior.

\section{Conclusion}

The fascination with Bosio's death that filled the press and captivated the attention of many residents of the capital reflected an expanding public sphere shaped by celebrity, the conventions of opera, and the growing influence of commercial forces that made cultural boundaries increasingly ambiguous. In this respect attempts to both deify Bosio as a great artist and treat her as a commercialized object to be consumed by an implicitly male public not only reflected the larger dynamics of celebrity, which seeks to construct and then undermine a distinction between the public and the private [Lilti, 
2017, p. 10, 80-81], but also the growing diversity of tastes and voices emerging from the Russian Empire's urban middle classes through the press in the mid-nineteenth century. The growing Reform Era press sought to constitute the public as a reading public, made up primarily of the "middle stratum" of Russian society that consisted of "gentry in state service, non-noble civil servants, provincial landowners, wealthy merchants, manufacturers, professionals, and some townspeople" [Raykhlina, 2018 , p. 2]. This heterogeneous audience was being formed into a reading public through genres like the newspaper feuilleton which promiscuously combined topics that spanned "the 'high culture' of the thick journals and the 'middlebrow' culture of the popular daily press" [Dianina, 2003, p. 192]. While it is well-known that the intelligentsia voices that shaped much public discourse largely viewed commercial forces and the marketplace as reflections of petty-bourgeois vulgarity [Kelly, 2001, p. 104111], Yekaterina Raykhlina has recently argued that in the middle decades of the nineteenth century "both intelligentsia culture (focused on the gulf between themselves and the narod) and genuinely popular bourgeois culture (flourishing in cities and provinces) existed side by side" [Raykhlina, 2018, p. 282]. By fixating on reactions to Bosio's death that reflected commercialism while also holding her up as proof of the cultural sophistication of Petersburg's public, the press both contributed to this blurring of cultural boundaries and the growing anxiety surrounding them.

A celebrity female opera performer like Bosio was uniquely positioned to capture the tensions of these developments. A representative of an art form that was both popular and increasingly commercialized yet associated with cultural prestige and a woman whose presence in the public sphere was a testament to changing social norms, Bosio encapsulated many of the changes unfolding in Reform Era Russia and revealed their highly gendered nature. In Bosio's death operatic tropes of female death combined with associations of women with commercialism and concern over the effects of women in public on men (see for example, [Felski, 1995]). Her death demonstrates an expanding public sphere shaped by celebrity and the press that resists easy categorization in terms of intelligentsia or bourgeois cultural narratives. Instead, reactions to the death of Bosio make clear that these categories were not mutually exclusive but were part of an increasingly heterogeneous public sphere that continued to expand in the coming decades [McReynolds, 2003; Brooks, 2019], one in which the boundaries between intelligentsia values, celebrity culture, and commercial forces blurred in ways that produced both fascination and anxiety that would persist and intensify throughout the imperial era.

\section{Primary Sources}

Российский государственный архив литературы и искусства (РГАЛИ). Ф. 2430. Оп. 1. Д. 1388. Анджиолина Бозио // Русский художественный листок. 1859. № 13, 1 мая.

Анджиолина Бозио // Северный цветок. 1859. № 15. 11 апреля.

Барон Икс. Заметки русскаго барона // Русский мир. 1859. № 15.10 апреля.

Бернаикий В.A. Из золотого века итальянской оперы в Петербурге // Русская старина. 1916. № 168. Октябрь.

Воеводский Д.М. Анджелина Бозио // Бирюч Петроградских государственных театров. 1918. № 5. Декабрь.

Дневник знакомаго человека // Иллюстрация. 1859. № 63.9 апреля.

Дневник знакомаго человека // Иллюстрация. 1859. № 69. 14 мая.

Замечательныя женщины умершия в 1858-1859 году // Ласточка. 1860. № 1. январь.

Кончина Анджиолины Бозио // Театральный и музыкальный вестник. 1859. № 14.5 апреля.

Кончина и похороны г-жи Бозио // Нувеллист. 1859. Май.

Новости и слухи // Северная пчела. 1859. 10 апреля.

Общественная жизнь в Петербурге // Русское слово. 1859. № 5. Май.

Памятник Бозио // Нувеллист. 1861. Октябрь.

Панаева А.Я. Воспоминания. М.: Захаров, 2002. 445 с.

Петербургская летопись // Санкт-Петербургские ведомости. 1859. 19 апреля; 10 мая

Panonopm. Вести отвсюду // Театральный и музыкальный вестник. 1859. № 15.19 апреля.

Русский художественный листок. 1859. № 13. 1 мая.

Фельтон // Русский инвалид. 1859. 5 апреля.

Фельтон // Санкт-Петербургские ведомости. 1859. 5 апреля.

Death of Madam Bosio // The Daily Telegraph (London). 1859. 15 April. 


\section{References}

Berlanstein, L. (2001), Daughters of Eve: A Cultural History of French Theater Women from the Old Regime to the Fin de Siècle, Harvard University Press, Cambridge, USA, 300 p.

Binyon, T. J. (2003), Pushkin: A Biography, Alfred A. Knopf, New York, USA, 727 p.

Bronfen, E. (1992), Over Her Dead Body: Death, Femininity, and the Aesthetic, Manchester University Press, Manchester, UK, $460 \mathrm{p}$.

Brooks, J. (2019), The Firebird and the Fox: Russian Culture under Tsars and Bolsheviks, Cambridge University Press, Cambridge, UK, $330 \mathrm{p}$.

Buckler, J. (2000), The Literary Lorgnette: Attending Opera in Imperial Russia, Stanford University Press, Stanford, USA, 294 p.

Chaouche, S. \& C. Sadoun-Édouard (2015), Consuming Female Performers: 1850s-1950s, Classiques Garnier, Paris, France, 383 p.

Clément, C. (1988), Opera, or, The Undoing of Women, University of Minnesota Press, Minneapolis, USA, $201 \mathrm{p}$.

Clowes, E., Kassow S. \& J. West (1991), Between Tsar and People: Educated Society and the Quest for Public Identity in Late Imperial Russia, Princeton University Press, Princeton, USA, 383 p.

Cowgill, R. \& H. Poriss (2012), The Arts of the Prima Donna in the Long Nineteenth Century, Oxford University Press, New York, USA, 368 p.

Curl, J. S., (1972), The Victorian Celebration of Death, David \& Charles, Newton Abbot, UK, 222 p.

Dianina, K. (2003), "The Feuilleton: An Everyday Guide to Public Culture in the Age of the Great Reforms," Slavic and East European Journal, № 2, pp. 187-210.

Dijkstra, B. (1986), Idols of Perversity: Fantasies of Feminine Evil in Fin-de-Siècle Culture, Oxford University Press, New York, USA, 453 p.

Eklof, B., Bushnell J. \& L. G. Zakharova (1994), Russia's Great Reforms, 1855-1881, Indiana University Press, Bloomington, USA, $297 \mathrm{p}$.

Felski, R. (1995), The Gender of Modernity, Harvard University Press, Cambridge, USA, 247 p.

Fishzon, A. (2013), Fandom, Authenticity, and Opera: Mad Acts and Letter Scenes in Fin-de-Siècle Russia, Palgrave Macmillan, Basingstoke, UK, 273 p.

Frame, M. (2006), School for Citizens: Theater and Civil Society in Imperial Russia, Yale University Press, New Haven, USA, 262 p.

Kelly, C. (2001), Refining Russia: Advice Literature, Polite Culture, and Gender from Catherine to Yeltsin, Oxford University Press, UK, 438 p.

Kublitskiy M. E. (1874), Istoriya opery v luchshikh ee predstavitelyakh. Kompozitory. Pevtsy. Pevitsy [History of opera in its best representatives. Composers. Male singers. Female singers], S. P. Yakovlev, Moscow, Russia, $310 \mathrm{p}$.

Lilti, A. (2017), The Invention of Celebrity: 1750-1850, Polity Press, Cambridge, UK, 354 p.

Lincoln, B. (1990), The Great Reforms: Autocracy, Bureaucracy, and the Politics of Change in Imperial Russia, Northern Illinois University Press, DeKalb, USA, 281 p.

McClary, S. (1991), Feminine Endings: Music, Gender, and Sexuality, University of Minnesota Press, Minneapolis, USA, $220 \mathrm{p}$.

McReynolds, L. (1991), The News Under Russia's Old Regime: The Development of a MassCirculation Press, Princeton University Press, Princeton, USA, 313 p.

McReynolds, L. (2003), Russia at Play: Leisure Activities at the End of the Tsarist Era, Cornell University Press, Ithaca, USA, 309 p.

Raykhlina, Y. (2018), Russian Literary Marketplace: Periodicals, Social Identity, and Publishing for the Middle Stratum in Imperial Russia, 1825-1865: PhD dissertation, Washington, D.C., USA, 308 p.

Rowley, A. (2013), Open Letters: Russian Popular Culture and the Picture Postcard, 1880-1922, University of Toronto Press, Toronto, Canada, $323 \mathrm{p}$.

Rutherford, S. (2006), The Prima Donna and Opera, 1815-1930, Cambridge University Press, Cambridge, UK, $381 \mathrm{p}$.

Senelick, L. (1991), "Eroticism in Early Theatrical Photography," Theatre History Studies, № 11, pp. 1-49.

Stites, R. (2005), Serfdom, Society, and the Arts in Imperial Russia: The Pleasure and the Power, Yale University Press, New Haven, USA, 586 p. 
Ther, P. (2014), Center Stage: Operatic Culture and Nation Building in Nineteenth-Century Central Europe, Purdue University Press, West Lafayette, USA, 306 p.

Vishnevskiy, V. E. (1941), Teatral'naya periodika. Tom 1: 1775-1917 [Theatrical periodicals. Volume 1: 1775-1917], Iskusstvo, Moscow, Russia, 128 p.

Дата поступления рукописи в редакцию 29.09.2021

\title{
ОПЕРНОСТЬ СМЕРТИ: ГЕНДЕР, РЫНОК И ПУБЛИЧНОЕ ПРОСТРАНСТВО ЭПОХИ ВЕЛИКИХ РЕФОРМ В СМЕРТИ АНДЖИОЛИНЫ БОЗИО
}

\author{
М. Клопфенстейн \\ Южно-Каролинский университет, 29208, Колумбия, Южная Каролина, США \\ matthew.klopfenstein87@gmail.com \\ ORCID: 0000-0003-0270-7520 \\ ResearcherID: ABF-9242-2021 \\ Scopus Author: 57222196910
}

Анализируется развитие гендеризованной культуры «селебрити» в России в XIX в. на примере смерти оперной певицы Анджиолины Бозио в 1859 г. А. Бозио была одной из выдающих знаменитостей своего времени, и ее смерть стала грандиозным общественным явлением. Рассматриваются отзывы о смерти певицы в столичных газетах и журналах, чтобы доказать, как фигура известной исполнительницы отражала важные изменения в публичной сфере в эпоху Великих реформ. Отзывы показывают, что женщины - театральные знаменитости показывали растущую роль коммерческих сил в публичном пространстве, что вызывало беспокойство многих обозревателей. Данная статья демонстрирует, что знаменитые женщины расширяли динамику развития публичной сферы в России в середине XIX в., что видно на страницах столичной прессы. А. Бозио воплотила неясный статус оперы как популярный и элитный жанр искусства, а также особую культуру эмоции, связанную с оперой. Более того, ее смерть показала роль гендера в создании и динамике развития «селебрити» в печатной публичной сфере. Анализ отзывов на смерть певицы четко демонстрирует, что гендерные тропы и условность оперы широко распространились за пределами театра и влияли на публичную жизнь. Через призму ее смерти можно видеть развитие публичной сферы, в которой культурные границы смазывались из-за влияния рыночных сил, и всеевропейская условность оперы стала образцом для публичного поведения.

Ключевые слова: СМИ, смерть, публичная сфера, гендер, опера, «селебрити», эпоха Великих реформ.

\section{Библиографический список}

Вишневский В.Е. Театральная периодика. Т. 1: 1775-1917. М.: Искусство, 1941. 128 с.

Кублицкий M.E. История оперы в лучших ее представителях. Композиторы. Певцы. Певицы. М.: С.П. Яковлев, 1874. 310 с.

Berlanstein L. Daughters of Eve: A Cultural History of French Theater Women from the Old Regime to the Fin de Siècle. Cambridge: Harvard University Press, 2001. 300 p.

Binyon T.J. Pushkin: A Biography. New York: Alfred A. Knopf, 2003. 727 p.

Bronfen E. Over Her Dead Body: Death, Femininity, and the Aesthetic. Manchester: Manchester University Press, 1992. 460 p.

Brooks J. The Firebird and the Fox: Russian Culture under Tsars and Bolsheviks. Cambridge, UK: Cambridge University Press, 2019. 330 p.

Buckler J. The Literary Lorgnette: Attending Opera in Imperial Russia. Stanford: Stanford University Press, 2000. 294 p.

Chaouche S., Sadoun-Édouard C. Consuming Female Performers: 1850s-1950s. Paris: Classiques Garnier, 2015. 383 p.

Clément C. Opera, or, The Undoing of Women. Minneapolis: University of Minnesota Press, 1988. 201 p.

Clowes E., Kassow S., West J. Between Tsar and People: Educated Society and the Quest for Public Identity in Late Imperial Russia. Princeton: Princeton University Press, 1991. 383 p.

Cowgill R., Poriss H. The Arts of the Prima Donna in the Long Nineteenth Century. New York: Oxford University Press, 2012. 368 p.

Curl J.S. The Victorian Celebration of Death. Newton Abbot: David \& Charles, 1972. 222 p.

Dianina K. The Feuilleton: An Everyday Guide to Public Culture in the Age of the Great Reforms // Slavic and East European Journal. 2003. № 2. P. 187-210. 
Dijkstra B. Idols of Perversity: Fantasies of Feminine Evil in Fin-de-Siècle Culture. New York: Oxford University Press, 1986. 453 p.

Eklof B., Bushnell J., Zakharova L.G. Russia’s Great Reforms, 1855-1881. Bloomington: Indiana University Press, 1994. 297 p.

Felski R. The Gender of Modernity. Cambridge: Harvard University Press, 1995. 247 p.

Fishzon A. Fandom, Authenticity, and Opera: Mad Acts and Letter Scenes in Fin-de-Siècle Russia. Basingstoke: Palgrave Macmillan, 2013. 273 p.

Frame M. School for Citizens: Theater and Civil Society in Imperial Russia. New Haven: Yale University Press, 2006. 262 p.

Kelly C. Refining Russia: Advice Literature, Polite Culture, and Gender from Catherine to Yeltsin. Oxford: Oxford University Press, 2001. 438 p.

Lilti A. The Invention of Celebrity: 1750-1850. Cambridge, UK: Polity Press, 2017. 354 p.

Lincoln B. The Great Reforms: Autocracy, Bureaucracy, and the Politics of Change in Imperial Russia. DeKalb: Northern Illinois University Press, 1990. 281 p.

McClary S. Feminine Endings: Music, Gender, and Sexuality. Minneapolis: University of Minnesota Press, 1991. 220 p.

McReynolds L. The News Under Russia's Old Regime: The Development of a Mass-Circulation Press. Princeton: Princeton University Press, 1991. 313 p.

McReynolds L. Russia at Play: Leisure Activities at the End of the Tsarist Era. Ithaca: Cornell University Press, 2003. 309 p.

Raykhlina $Y$. Russian Literary Marketplace: Periodicals, Social Identity, and Publishing for the Middle Stratum in Imperial Russia, 1825-1865: PhD Dissertation, Georgetown University. Washington D.C., United States, 2018. 308 p.

Rowley A. Open Letters: Russian Popular Culture and the Picture Postcard, 1880-1922. Toronto: University of Toronto Press, 2013. 323 p.

Rutherford S. The Prima Donna and Opera, 1815-1930. Cambridge, UK: Cambridge University Press, 2006. $381 \mathrm{p}$.

Senelick L. Eroticism in Early Theatrical Photography // Theatre History Studies. 1991. № 11. P. 1-49.

Stites $R$. Serfdom, Society, and the Arts in Imperial Russia: The Pleasure and the Power. New Haven: Yale University Press, 2005. 586 p.

Ther P. Center Stage: Operatic Culture and Nation Building in Nineteenth-Century Central Europe. West Lafayette: Purdue University Press, 2014. 306 p. 